\title{
Childrearing Practices and Children's Behaviours: A Correlational Study Considering Gender and School Age of Children
}

\author{
Jéssica Aline Rovaris, Alessandra Turini Bolsoni-Silva \\ Universidade Estadual Paulista, Bauru, Brazil \\ Email: jessica.rovaris@gmail.com
}

How to cite this paper: Rovaris, J. A., \& Bolsoni-Silva, A. T. (2018). Childrearing Practices and Children's Behaviours: A Correlational Study Considering Gender and School Age of Children. Psychology, 9, 1245-1261.

https://doi.org/10.4236/psych.2018.96076

Received: April 2, 2018

Accepted: June 11, 2018

Published: June 14, 2018

Copyright $\odot 2018$ by authors and Scientific Research Publishing Inc. This work is licensed under the Creative Commons Attribution International License (CC BY 4.0).

http://creativecommons.org/licenses/by/4.0/

\begin{abstract}
In this work we attempted to describe and correlate specific parenting practices and child behavior of children differentiated by problem behavior, education and sex. Attended 155 mothers of children enrolled in public schools, attending preschool or elementary school of both sexes, who answered the instruments: CBCL, RE-HSE-P and QRSH-P (version for parents). Data were analyzed statistically using the Pearson correlation test. The results showed that there are differences in the childrearing practices of skillful mothers and repertoire when correlated to pre-school and school children, especially if they are also differentiated by sex. The girls were the most skillful and the boys had more behavior problems.
\end{abstract}

\section{Keywords}

Educational Practices, Social Skills, Behavior Problems, Correlational Analysis

\section{Introduction}

The course of children's development is influenced by diverse variables; among them, there are: child's school grade, if the child is male or female (Bolsoni-Silva, Levati, Guidulli, \& Marin, 2015; Bolsoni-Silva \& Loureiro, 2016) and childrearing practices by parents or caregivers (Alvarenga, Weber, \& Bolsoni-Silva, 2016; Bolsoni-Silva, Marturano, \& Rubinger, 2010). Such parental behaviours may act in the social performance of the child through social-skill constructs and problems of behaviour (Bornstein, Hahn \& Haynes, 2010; Reynolds, Sander, \& Irvin, 2010).

According to Del Prette (2013), social skills could be understood by means of 
the concept of social competence:

Social competence is an evaluative attribute of this performance, which depends on its functionality and coherence with the individual's thoughts and feelings.

Social skills are those classes of behaviour that exist in the individual's repertoire and contribute to socially competent performance (p. 49).

On the other hand, behaviour problems are considered excess (or deficit) behaviours, which negatively affect the interaction of the child with adults and their friends. These problems also make the child's access to Contingencies of reinforcement difficult (Bolsoni-Silva, Loureiro, \& Marturano, 2016b).

According to Achenbach \& Rescorla (2001) classification, there are two types of behaviour problems. The externalizing problems comprise one of them. They appear in the child's relationship with other people and they are dramatically targeted at fathers, mothers and caregivers' complaints (Sierra \& Veja, 2014). There are also the internalizing problems, whose demonstration happens in the relationship of the individual with himself, such as depression, social isolation, anxiety, phobia and sorrow (Achenbach \& Rescorla, 2001).

In relation to gender, it is common for boys to demonstrate more behaviour problems than girls, especially the externalizing ones, such as: involvement in conflicts with friends, involvement in fights, greater aggressivity, impulsiveness and disrespect. Therefore, they exhibit more aggressive, impulsive and disrespectful behaviours. On the other hand, girls are usually more skillful and they demonstrate less externalizing behaviours (Bolsoni-Silva, Silveira, Cunha, Silva, \& Orti, 2016; Cosentino-Rocha \& Linhares, 2013; Landale, Lanza, Hillemeier, \& Oropesa, 2013).

Regarding this subject, Reyna \& Brussino (2015) found more social skills in girls up to five years old, even though boys demonstrate more behaviour problems from three years old already. This result is similar to the one found by Bolsoni-Silva \& Loureiro (2016), whose set of social skills was greater for girls at the Primary school only. On the other hand, the study by Emerich, Rocha, Silvares, \& Gonçalves (2012) verified that in CBCL scales related to anxiety-depression, withdrawal-depression, somatic complaints and internalization, boys and girls from six to eleven years old showed similar scores.

Therefore, there seems not to be an agreement in literature related to the influence of gender in child's behaviour, especially when different sample groups are considered, such as Elementary School girls (Bolsoni-Silva \& Loureiro, 2016; Emech et al., 2012) or Kindergarten boys (Reyna \& Brussino, 2015). Thus, it is important that new investigations occur in order to elucidate the latter issues.

Still in relation to the variables that influence the child's behaviour, some studies pointed out that children from the upper school grades exhibit more social skills and less behaviour problems (Berry \& O'Connor, 2010; Konold, Jamison, Staton-Chapman, \& Rimm-Kaufman, 2010; Pizato, Marturano, \& Fontaine, 
2014), but these results are not conclusive, because recent researches (Bolsoni-Silva \& Loureiro, 2016; Bolsoni-Silva et al., 2015) did not find such correlation.

Besides gender and school grade, parental childrearing practices are considered strong predictors to child behaviour (Bolsoni-Silva, Loureiro, \& Marturano, 2016a; Kim, Doh, Hong, \& Choi, 2011; Leme \& Marturano, 2014; Sierra \& Veja, 2014; Teixeira, Marino, \& Carreira, 2015). These practices are understood as the strategies applied by the parents aiming at align their children to the acquisition of some determined behaviours and the suppression of others, which are considered socially unfavorable or inadequate (Newcombe, 1999). These practices may be classified as positive or negative parental practices (Gomide, 2006).

The frequency in the usage of positive or negative educational practices depends, mostly, on social skills that mothers and fathers hold (Bolsoni-Silva et al., 2016a). Bolsoni-Silva et al. (2016a) named this set of abilities as Parental Social Educational Skills (HSE-P), because they are the set of skills owned by the parents, since it is the set of parents' abilities, which are applicable to the children's childrearing practice. Parents with more HSE-P adopt positive practices in children's education more frequently, such as affection, care and attention offer, without establishing any limits; thus, they offer behaviour models more likely to be socially reinforced as well as less probable to cause problems in the future (Alvarenga et al., 2016).

Associations between maternal practices children's behaviour are frequent in literature (Alvarenga et al., 2016; Bartholomeu, Montiel, Flamenghi Jr., \& Machado, 2016; Sierra \& Veja, 2014). In the study by Sierra \& Veja (2014), the establishment of consistent parental practices was positively associated with a satisfactory parents-children relationship. Moreover, data suggested that low communication, involvement and commitment of parents towards the children boosted the children's chances to develop externalizing behaviour problems. Another study with similar data was performed by Kim et al. (2011), in which it is verified that the increase in social skills of mothers and children, through an intervention, enhanced the decrease in children's aggressive behaviours, in addition to the mothers' social abilities. The recent literature is consistent with demonstrating the relationship of interdependence between mothers' and children's behaviours. In this way, the presented literature demonstrates that analyses were carried out intending to more deeply comprehend the relationship between childrearing practices from fathers and mothers and the children's behaviours, mostly in cases of behaviours considered risky to the children's health and social well-being.

The present research is justified as far as chase for associating specific behaviours related to childrearing practices and mothers and children's behaviours as to gather answers to questions which are unclear in this context. These questions are referred to describing correlations between parental behaviours (positive and negative practices) and child's behaviours (social skills and behaviour problems), 
considering the presence of behaviour problems, gender and the child's school grade.

Therefore, the present work aims to describe correlations between positive and negative maternal childrearing practices, social skills and behaviour problems to clinic and non-clinic groups (to childhood behaviour problem), pre-school and school-age groups, and the child's gender.

\section{Method}

\subsection{Participants}

The participants of this study were 155 mothers of children enrolled in public schools from the midwest of the State of Sao Paulo. These children were at the pre-school level in Municipal Government Schools for Children's Education (36 girls and 43 boys) or Primary school children in Municipal Government Elementary Schools (26 girls and 50 boys). These children were both male and female, summing up a total of 93 boys and 62 girls. They were, on average, 6.38 years old $(\mathrm{SD}=2.82)$. Pre-school children were, on average, 4.16 years old $(\mathrm{SD}=$ 1.18). The Primary school children were, on average, 8.6 years old $(S D=2.09)$. Also, the average age of the respondent mothers was 27.8 years old $(\mathrm{SD}=12.4)$. Among the ones evaluated and diagnosed with behaviour problems, $60 \%$ were boys and $35 \%$ were girls. This difference related to gender remained even when the sample was separated regarding the school grade; thus, among the pre-school children, $58 \%$ of the ones with behaviour problems were boys and $35 \%$ girls. Among the Primary ones, $61 \%$ were boys and $35 \%$ were girls.

Seventy-nine mothers of children enrolled in pre-schools were interviewed, who were aged between three and six years old; and 76 mothers of children enrolled in Primary Schools, who were aged between seven and twelve years old. Considering the mothers' sample: (a) $61.2 \%$ were married, (b) $16.1 \%$ had a common-law marriage, $16.7 \%$ were single, $3.22 \%$ were divorced, $0.6 \%$ were widows and $0.6 \%$ did not present marital status information; (b) regarding the educational level, $34.8 \%$ of the sample had (complete or incomplete) Primary level, $46.4 \%$ completed the Secondary level, $17.4 \%$ had a degree from an Institution of Higher Education and $1.7 \%$ did not present educational level information; (c) regarding family income, in terms of minimum wage, the data shows: $27 \%$ - up to one wage; $35.4 \%$ - 2 minimum wages; $21.2 \%$ - 3 minimum wages; $4.5 \%$ - 4 wages; $3.20 \%$ - 5 wages; $5.16 \%$ over 6 wages and $2.5 \%$ did not present family income information.

\subsection{Instruments}

\subsubsection{Child Behaviour Checklist-CBCL}

(Achenbach \& Rescorla, 2001) for pre-school and Primary-Secondary School ones (from 1.5 to 5 years old and from 6 to 18 years old, respectively). This checklist investigates, from parents' reports, the frequency of 113 or 118 (depending on age range) answers which indicate behaviour problems through the scores "not true $=0$ ", "somewhat true $=1$ " and "very true $=2$ ", as well as 
through questions related to the child's school, familiar social life. Results are organized into internalizing, externalizing and total problems, which may be classified as clinical, borderline and non-clinical. The behaviour problems are evaluated according to the following scales: Internalizing Scale (Anxiety-Depression, Withdrawal-Depression, Somatic Complaints); Externalizing Scale (Rule-breaking behaviour and Aggressive behaviour); and Total Problems Scale (Internalizing and Externalizing problems and also Attention and Thought problems) (Achenbach \& Rescorla, 2001).

\subsubsection{Interview Script of Parental Social Educative Skills-RE-HSE-P}

(Bolsoni-Silva et al., 2016), which evaluates (functionally and in terms of frequency) the behaviour of parents-caregivers, children and contextual variables. Concerning this evaluation, the instrument uses open questions, organised in greater categories, which are later subdivided in smaller ones, they are: 1) Parental Social Childrearing Skills-HSE-P (related to positive childrearing practices); 2) Conjugal Social Childrearing Skills (HSE-P-conjugal), specific from conjugal interaction; 3) Negative childrearing practices; 5) Childhood Social Skills and 7) Contextual variables contingent to parental behaviours. This instrument has approval from the Federal Council of Psychology (Conselho Federal de Psicologia) and, regarding the internal consistency, it obtained an alpha value of 0.846 . This instrument has two factors: Positive Total and Negative Total and it classify children with and without behaviour problems, school-aged children from pre-school aged children, and boys versus girls. From Roc Curves, it is presented cut-off points for the constructs measured by the instrument.

\subsubsection{Questionnaire of Socially Skilled}

It is intended for an evaluation instrument of children's social abilities from four to seven years old through their mothers' report. It is consisted of 18 questions measured by means of a scale of three scouring points $(2=$ applies; $1=$ partially applies; $0=$ do not apply). Those questions are in accordance to the social skills categories proposed by Del Prette \& Del Prette (2002), who affirm that those abilities have implications in the acquisition of boosters, besides impacting in the children's social and academic compentence. For the instrument correction, the scores are summed up, obtaining a total score of the evaluated abilities. The study of the QRSH-Parents psychometric properties indicated satisfactory internal consistency (alpha 0.82) and predictor $\mathrm{O}$ estudo sobre as propriedades psicométricas do QRSH-Parents indicou consistência interna satisfatória (alfa 0.82) e predictive and discriminating validity, thus, it is able to differenciate children with and without behaviour problems (Bolsoni-Silva et al., 2011).

\subsection{Data Collection Procedure}

After the approval of the research by the Secretary of Education and the Research Ethics Comitee of Universidade Estadual Júlio de Mesquita Filho (UNESP), Children's Education Schools and Primary Schools were contacted as 
to check their availability to participate in the project. The interviews with mothers were made at the schools, where their respective children were enrolled, or at the participants' residence. At schools, the goals of the research were informed to the principals or pedagogic coordinators and, after that, the explanations were exhibited to the participant mothers. The mothers who accepted to participate signed down a Term of Free and Aware Consent and attended to the instruments CBCL, RE-HSE-P and QRSH related to their children. As for feedback, mothers were asked if they were interested in specialised attendance for their children. Additionally, at schools, informative lectures about childrearing practices and child behaviours were held. In addition, informative books about parental practices were given.

\subsection{Procedure and Data Treatment and Analysis}

After collecting data, the instruments were corrected according to appropriate instructions. Results related to CBCL permitted the identification of children with and without behaviour problems. Data from QSRH-Parents evaluated the children's social skills in order to complement the data from RE-HSE-P, from direct reports.

Data obtained from RE-HSE-P, considering the spontaneous answers from the mothers, was organised in the following analysis categories: Child Social Skills, Behaviour Problems, Parental Childrearing Social Skills (HSE-P), Social Skills in Conjugal Interaction (HSE-P-Conjugal), Negative Childrearing Practices (NCP), Negative Childrearing Practices in Conjugal Interaction (NCP-Conjugal). It was also utilized in the analyses the categories Positive Interaction and Negative Interaction, considering the first as the sum of positive practices and positive conjugal interaction from the mother, and the last as the sum of negative practices and negative conjugal interaction from the mother.

To perform the analyses, the categories from RE-HSE-P and the score of Social Skills from QRSH-Parents were used.

Then, the sample was divided into Pre-school children and Primary School children, which were organised in subgroups (boys and girls; with and without behaviour problems). After this organisation, Pearson Correlation tests were performed, considering the variables boys versus girls, and children with and without behaviour problems, being these ones both Pre-school and Primary School children. The correlations were evaluated by means of the following criteria: very strong $(>0.70)$, strong $(0.51-0.70)$, moderate $(0.26-0.50)$ and weak $(0-0.25)$.

\section{Results}

The results are presented in two tables. On Table 1, there is data referring to the correlations of the subgroup of Pre-school children. On the Table 2, there is the description of the findings referring to the subgroup of Primary School children. Both tables present data organised regarding gender and presence (or not) of 
Table 1. Correlations between children's behaviours with and without behaviour problems (according to CBCL), as well as boys and girls, and the behaviour categories from RE-HSE-P and scores of social skills from QRSH-Parents to the subgroup of Pre-school children.

\begin{tabular}{|c|c|c|c|c|c|c|c|c|c|}
\hline \multicolumn{10}{|c|}{ Pre school Children (n 79) } \\
\hline \multicolumn{10}{|c|}{ Without behaviour problems (n 40 ) } \\
\hline Items & 1 & 2 & 3 & 4 & 5 & 6 & 7 & 8 & 9 \\
\hline 1. QRSH - Parents & 1 & 0.026 & -0.172 & 0.159 & -0.244 & -0.07 & $0.324\left(^{*}\right)$ & -0.216 & 0.028 \\
\hline 2. Positive Interaction & & 1 & -0.17 & $0.390\left(^{*}\right)$ & 0.088 & $0.965\left(^{* *}\right)$ & $0.514\left(^{* *}\right)$ & -0.161 & -0.091 \\
\hline 3. Negative Interaction & & & 1 & -0.012 & 0.716 & -0.159 & -0.102 & $0.932(* *)$ & $0.571\left(^{* *}\right)$ \\
\hline 4. Social Skills & & & & 1 & -0.114 & $0.367\left(^{*}\right)$ & 0.228 & 0.04 & -0.123 \\
\hline 5. Behaviour Problem & & & & & 1 & 0.116 & -0.057 & $0.628(* *)$ & $0.499\left(^{* *}\right)$ \\
\hline 6. HSE-P & & & & & & 1 & 0.27 & -0.147 & -0.094 \\
\hline 7. HSE-P-Conjugal & & & & & & & 1 & -0.109 & -0.026 \\
\hline $\begin{array}{l}\text { 8. Negative Childrearing } \\
\text { Practices (NCP) }\end{array}$ & & & & & & & & 1 & 0.234 \\
\hline 9. NCP-Conjugal & & & & & & & & & 1 \\
\hline
\end{tabular}

\begin{tabular}{|c|c|c|c|c|c|c|c|c|c|}
\hline \multicolumn{10}{|c|}{ With behaviour problems (n 39) } \\
\hline Items & 1 & 2 & 3 & 4 & 5 & 6 & 7 & 8 & 9 \\
\hline 1. QRSH - Parents & 1 & 0.044 & -0.225 & 0.074 & -0.238 & 0.098 & -0.159 & -0.222 & -0.055 \\
\hline 2. Positive Interaction & & 1 & -0.012 & $0.642(* *)$ & $\left.0.3811^{*}\right)$ & $0.967(* *)$ & $0.553(* *)$ & 0.049 & -0.148 \\
\hline 3. Negative Interaction & & & 1 & 0.023 & $0.368\left(^{*}\right)$ & -0.063 & 0.159 & $0.923\left(^{* *}\right)$ & $0.401\left(^{*}\right)$ \\
\hline 4. Social Skills & & & & 1 & $0.335\left(^{*}\right)$ & $0.587(* *)$ & $0.465\left(^{(*}\right)$ & 0.141 & -0.276 \\
\hline 5. Behaviour Problem & & & & & 1 & $0.357\left(^{*}\right)$ & 0.247 & $0.392\left(^{*}\right)$ & 0.024 \\
\hline 6. HSE-P & & & & & & 1 & $0.322\left(^{*}\right)$ & 0.019 & -0.207 \\
\hline 7. HSE-P-Conjugal & & & & & & & 1 & 0.12 & 0.128 \\
\hline $\begin{array}{l}\text { 8. Negative Childrearing } \\
\text { Practices (NCP) }\end{array}$ & & & & & & & & 1 & 0.016 \\
\hline 9. NCP-Conjugal & & & & & & & & & 1 \\
\hline
\end{tabular}

\begin{tabular}{|c|c|c|c|c|c|c|c|c|c|}
\hline \multicolumn{10}{|c|}{ Girls (n 36) } \\
\hline Items & 1 & 2 & 3 & 4 & 5 & 6 & 7 & 8 & 9 \\
\hline 1. QRSH - Parents & 1 & -0.135 & $-0.389\left(^{*}\right)$ & -0.012 & $-0.646\left(^{\star \star}\right)$ & -0.124 & -0.058 & $\left.-0.426^{(* *}\right)$ & -0.061 \\
\hline 2. Positive Interaction & & 1 & -0.29 & 0.314 & 0.036 & $0.956\left({ }^{* *}\right)$ & 0.3 & -0.258 & -0.226 \\
\hline 3. Negative Interaction & & & 1 & 0.15 & $0.523(* *)$ & -0.327 & 0.075 & $0.962(* *)$ & $0.559^{(* *)}$ \\
\hline 4. Social Skills & & & & 1 & 0.011 & 0.249 & 0.26 & 0.149 & 0.07 \\
\hline 5. Behaviour Problem & & & & & 1 & -0.01 & 0.155 & $0.550\left(^{* *}\right)$ & 0.147 \\
\hline 6. HSE-P & & & & & & 1 & 0.007 & -0.284 & -0.277 \\
\hline 7. HSE-P-Conjugal & & & & & & & 1 & 0.042 & 0.131 \\
\hline $\begin{array}{l}\text { 8. Negative Childrearing } \\
\text { Practices (NCP) }\end{array}$ & & & & & & & & 1 & 0.31 \\
\hline 9. NCP-Conjugal & & & & & & & & & 1 \\
\hline
\end{tabular}




\section{Continued}

\begin{tabular}{|c|c|c|c|c|c|c|c|c|c|}
\hline \multicolumn{10}{|c|}{ Boys (n 43) } \\
\hline Items & 1 & 2 & 3 & 4 & 5 & 6 & 7 & 8 & 9 \\
\hline 1. QRSH - Parents & 1 & 0.103 & -0.03 & $0.394\left({ }^{* *}\right)$ & -0.068 & 0.091 & 0.111 & -0.102 & 0.142 \\
\hline 2. Positive Interaction & & 1 & 0.016 & $0.585\left(^{* *}\right)$ & $0.377\left(^{*}\right)$ & $0.980(* *)$ & $0.731\left({ }^{\star *}\right)$ & 0.037 & -0.037 \\
\hline 3. Negative Interaction & & & 1 & -0.118 & $0.573(* *)$ & -0.014 & 0.117 & $0.907(* *)$ & $0.472(* *)$ \\
\hline 4. Social Skills & & & & 1 & 0.177 & $0.583(* *)$ & $0.397(* *)$ & -0.015 & -0.248 \\
\hline 5. Behaviour Problem & & & & & 1 & $0.377\left(^{*}\right)$ & 0.25 & $0.537(* *)$ & 0.233 \\
\hline 6. HSE-P & & & & & & 1 & $0.583(* *)$ & 0.013 & -0.06 \\
\hline 7. HSE-P-Conjugal & & & & & & & 1 & 0.107 & 0.054 \\
\hline $\begin{array}{l}\text { 8. Negative Childrearing } \\
\text { Practices (NCP) }\end{array}$ & & & & & & & & 1 & 0.056 \\
\hline 9. NCP-Conjugal & & & & & & & & & 1 \\
\hline
\end{tabular}

${ }^{*}$ Significant differences at level of $\mathrm{p}$ value $\leq 0.05$. ${ }^{*}$ Significant differences at level of $\mathrm{p}$ value $\leq 0.01$.

behaviour problems.

It's noticeable on Table 1 , for children without behaviour problems, that the Positive Interaction illustrated direct and moderate association with the positive aspects of the relationship, like Child Social Skills, in addition to strong association with HSE-P, and HSE-P-Conjugal; Negative Interaction and behaviour Problems presented strong positive correlation with Negative Practices (NP) and Conjugal Negative Practices (NP-Conjugal). Results as concerns the group with behaviour problems were, partially, different. While associations with Negative Interaction remained the same to the group without problems, not only the Positive Interactions and Social Skills obtained strong correlations with positive aspects of the relationship (HSE-P, HSE-P-Conjugal and Social Skills-QRHS), but also with Behaviour Problems. Additionally, Behaviour Problems associated with negative aspects of the relationship, and also with the HSE-P.

For girls, the set of Social Skills was inversely proportional to the Behaviour Problems, the Negative Interaction and the Negative Practice. It was also noticed that the Social Skills were related to Positive Interactions and to HSE-P. On the other hand, the Behaviour Problems were strongly associated with Negative Practices; moderately with Negative Interactions. Still about girls, Positive Interaction was strongly associated with HSE-P and the Negative Interactions were associated with Behaviour Problems, Negative Practices and Negative Practices Conjugal. Concerning the boys, these correlations were partially different, because Positive Interaction and strong associations with positive aspects of the relationship (such as HSE-P and Child's Social Skills), also demonstrated correlation with Behaviour Problems, which were associated with HSE-P and strongly associated with Negative Practices.

Additionally, Social Skills had strong association with HSE-P and HSE-P-Conjugal, as well as Negative Interaction with Negative Practices and 
Negative Practices-Conjugal.

It is interesting to emphasise that, for this group, the HSE-P were strongly and positively associated with HSE-P-Conjugal.

According to the results presented in the Table 2, there were similarities between the behaviours observed in the group without behaviour problems and the girls' group. For both, Positive Interaction was positive and directly associated to Negative Interaction, Social Skills, HSE-P and HSE-P-Conjugal. However, only for behaviour problems' samples, there was also association with Negative Practices.

For girls and children without behaviour problems, Negative Interaction associated strongly and directly with Social Skills, behaviour Problems, HSE-P, Negative Practices and Conjugal-Negative-Practices. Also, Social Skills obtained strong positive associations with HSE-P, HSE-P-Conjugal and Negative Practices.

Behaviour Problems and HSE-P were strongly associated with Negative Practices. Only for girls, the HSE-P were associated with HSE-Conjugal; for this sample, Social Skills (according to QRSH) were directly associated to HSE-P-Conjugal.

The groups of boys and the groups of people with behaviour problems showed similar results. For both, social skills (according to QRSH) were moderately associated with HSE-P and HSE-P-Conjugal. In these cases, social skills were also strongly associated with Positive Interactions. Nevertheless, only for children with behaviour problems, there was association with HSE-P-Conjugal and Negative Interaction.

Still, for both groups (boys and children with behaviour problems), Positive Interaction obtained strong association with Social Skills, HSE-P and HSE-P-Conjugal; Negative Interaction presented strong, direct association with Negative Practices and Conjugal-Negative Practices. However, for boys, Negative Interaction was also strongly associated with Behaviour Problems. On the other hand, for these groups, Social Skills were strongly correlated with HSE-P and HSE-P-Conjugal. Additionally, Behaviour Problems had strong association with Negative Practices targeted to the child and to the respective spouse; Finally, HSE-P denoted correlation with HSE-P-Conjugal and Negative Practices revealed correlation with Conjugal-Negative Practices.

\section{Discussion}

This study aimed to describe correlations between Childrearing Parental Positive and Negative Practices, Behaviour Problems and Child's Social Skills into groups of children with and without problems of behaviour. These children were both male and female, pre-school and school aged. The obtained results suggest that the child's education age, singly, is not a critical factor to distinguish the behaviour of the groups. This finding is different from what is stated in other studies (Berry \& O'Connor, 2010; Pizato et al., 2014). Yet, when related to factors such 
Table 2. Results of correlations of children's behaviours with and without Behaviour Problems (according to CBCL), and regarding to boys and girls, with the behaviour categories of RE-HSE-P and score of Social Skills of QRSH-Parents for the subgroup of school-aged children.

\begin{tabular}{|c|c|c|c|c|c|c|c|c|c|}
\hline \multicolumn{10}{|c|}{ Elementary School Children (n 76) } \\
\hline \multicolumn{10}{|c|}{ Without behaviour problems (n 37) } \\
\hline Items & 1 & 2 & 3 & 4 & 5 & 6 & 7 & 8 & 9 \\
\hline 1. QRSH - Parents & 1 & 0.135 & 0.089 & 0.06 & 0.042 & 0.129 & 0.098 & 0.024 & 0.226 \\
\hline 2. Positive Interaction & & 1 & $0.558\left(^{\star *}\right)$ & $0.587(* *)$ & 0.197 & $0.985\left(^{* *}\right)$ & $0.563(* *)$ & $0.599\left(^{* *}\right)$ & 0.091 \\
\hline 3. Negative Interaction & & & 1 & $0.464(* *)$ & $0.474(* *)$ & $0.568\left(^{* *}\right)$ & 0.229 & $0.957(* *)$ & $0.506(* *)$ \\
\hline 4. Social Skills & & & & 1 & 0.306 & $0.545(* *)$ & $0.492(* *)$ & $0.528\left(^{* *}\right)$ & -0.014 \\
\hline 5. Behaviour Problem & & & & & 1 & 0.218 & -0.005 & $0.485\left(^{\star *}\right)$ & 0.146 \\
\hline 6. HSE-P & & & & & & 1 & $0.413\left(^{*}\right)$ & $0.603(* *)$ & 0.111 \\
\hline 7. HSE-P-Conjugal & & & & & & & 1 & 0.275 & -0.05 \\
\hline $\begin{array}{l}\text { 8. Negative Childrearing } \\
\text { Practices (NCP) }\end{array}$ & & & & & & & & 1 & 0.232 \\
\hline 9. NCP-Conjugal & & & & & & & & & 1 \\
\hline \multicolumn{10}{|c|}{ With behaviour problems (n 41) } \\
\hline Items & 1 & 2 & 3 & 4 & 5 & 6 & 7 & 8 & 9 \\
\hline 1. QRSH - Parents & 1 & $0.424(* *)$ & -0.102 & $0.449\left(^{* *}\right)$ & -0.295 & 0.39 & $0.344\left(^{*}\right)$ & -0.014 & -0.181 \\
\hline 2. Positive Interaction & & 1 & -0.014 & $0.659\left(^{* *}\right)$ & -0.073 & $0.979\left(^{* *}\right)$ & $0.567(* *)$ & 0.099 & -0.168 \\
\hline 3. Negative Interaction & & & 1 & 0.088 & $0.766\left(^{* *}\right)$ & 0.003 & -0.074 & $0.877(* *)$ & $0.730(* *)$ \\
\hline 4. Social Skills & & & & 1 & -0.073 & $0.660\left(^{* *}\right)$ & $0.312\left(^{*}\right)$ & 0.146 & -0.034 \\
\hline 5. Behaviour Problem & & & & & 1 & -0.082 & 0.002 & $0.708\left(^{* *}\right)$ & $0.508\left({ }^{* *}\right)$ \\
\hline 6. HSE-P & & & & & & 1 & $0.388\left(^{*}\right)$ & 0.108 & -0.148 \\
\hline 7. HSE-P-Conjugal & & & & & & & 1 & 0.011 & -0.163 \\
\hline $\begin{array}{l}\text { 8. Negative Childrearing } \\
\text { Practices (NCP) }\end{array}$ & & & & & & & & 1 & $0.313\left(^{*}\right)$ \\
\hline 9. NCP-Conjugal & & & & & & & & & 1 \\
\hline
\end{tabular}

\begin{tabular}{|c|c|c|c|c|c|c|c|c|c|}
\hline \multicolumn{10}{|c|}{ Girls (n 28) } \\
\hline Items & 1 & 2 & 3 & 4 & 5 & 6 & 7 & 8 & 9 \\
\hline 1. QRSH - Parents & 1 & 0.292 & 0.096 & 0.301 & -0.151 & 0.24 & $0.399\left(^{*}\right)$ & -0.018 & 0.365 \\
\hline 2. Positive Interaction & & 1 & $0.581(* *)$ & $0.736(* *)$ & 0.311 & $0.985\left(^{(*}\right)$ & $0.591(* *)$ & $0.573(* *)$ & 0.231 \\
\hline 3. Negative Interaction & & & 1 & $0.533(* *)$ & $\left.0.5999^{(*}\right)$ & $0.574(* *)$ & 0.333 & $0.953(* *)$ & $0.493\left(^{* *}\right)$ \\
\hline 4. Social Skills & & & & 1 & 0.268 & $0.727(* *)$ & $0.426\left(^{*}\right)$ & $0.564\left(^{* *}\right)$ & 0.101 \\
\hline 5. Behaviour Problem & & & & & 1 & 0.28 & 0.309 & $0.617\left(^{\star \star}\right)$ & 0.161 \\
\hline 6. HSE-P & & & & & & 1 & $0.445\left(^{*}\right)$ & $0.563\left({ }^{\star *}\right)$ & 0.238 \\
\hline 7. HSE-P-Conjugal & & & & & & & 1 & 0.344 & 0.085 \\
\hline $\begin{array}{l}\text { 8. Negative Childrearing } \\
\text { Practices (NCP) }\end{array}$ & & & & & & & & 1 & 0.207 \\
\hline 9. NCP-Conjugal & & & & & & & & & 1 \\
\hline
\end{tabular}




\section{Continued}

\begin{tabular}{|c|c|c|c|c|c|c|c|c|c|}
\hline \multicolumn{10}{|c|}{ Boys (n 50) } \\
\hline Items & 1 & 2 & 3 & 4 & 5 & 6 & 7 & 8 & 9 \\
\hline 1. QRSH - Parents & 1 & $0.345\left(^{*}\right)$ & -0.115 & $0.284\left(^{*}\right)$ & -0.172 & $0.318\left(^{*}\right)$ & 0.264 & -0.021 & -0.213 \\
\hline 2. Positive Interaction & & 1 & -0.048 & $\left.0.5599^{* *}\right)$ & -0.083 & $\left.0.977^{(* *}\right)$ & $0.561(* *)$ & 0.088 & -0.239 \\
\hline 3. Negative Interaction & & & 1 & 0.059 & $\left.0.6933^{* *}\right)$ & -0.022 & -0.121 & $0.903(* \star)$ & $\left.0.7466^{* *}\right)$ \\
\hline 4. Social Skills & & & & 1 & 0.017 & $0.528\left(^{* *}\right)$ & $0.386\left(^{* *}\right)$ & 0.14 & -0.09 \\
\hline 5. Behaviour Problem & & & & & 1 & -0.066 & -0.103 & $0.646(* *)$ & $\left.0.4866^{(*}\right)$ \\
\hline 6. HSE-P & & & & & & 1 & $0.371\left(^{\star *}\right)$ & 0.106 & -0.211 \\
\hline 7. HSE-P-Conjugal & & & & & & & 1 & -0.026 & -0.22 \\
\hline $\begin{array}{l}\text { 8. Negative Childrearing } \\
\text { Practices (NCP) }\end{array}$ & & & & & & & & 1 & $0.387\left({ }^{* *}\right)$ \\
\hline 9. NCP-Conjugal & & & & & & & & & 1 \\
\hline
\end{tabular}

*Significant differences at level of $\mathrm{p}$ value $\leq 0.05$. ${ }^{*}$ Significant differences at level of $\mathrm{p}$ value $\leq 0.01$.

as gender and diagnostic for behaviour problems, some differences appear (Bolsoni-Silva et al., 2015; Bolsoni-Silva et al., 2016a; Emerich et al., 2012).

Initially, it is important to mention that, in the analysed sample, the quantity of girls without behaviour problems was bigger than boys', as well as most of the sample of children with behaviour problems was consisted by boys. This factor may explain coincidences in results found for girls and children without behaviour problems and for boys and children with behaviour problems, considering both pre-school and school-aged children.

With respect to the pre-school group, mothers of children without behaviour problems and girls presented HSE-P addressed to the child's social skills and negative practices addressed to the behaviour problems (Bolsoni-Silva et al., 2016a; Sierra \& Veja, 2014). In relation to girls, there was a specific feature: the children's social skills caused a decrease in the chances for mothers to use negative practices and for the emission, by children, of behaviour problems. It is possible to infer that these mothers, by using positive practices, were able to reinforce skilled behaviours of their daughters and teach them social skills concurrent to behaviour problems (Bueno et al., 2011; Macedo \& Sperg, 2013; Meyer et al., 2010).

This finding also indicates double directionality of interactions established between child and mother. That means: not only the mother's behaviour influences the child's, but also the opposite happens. Regarding this situation, Kim, et al. (2011) demonstrated that more aggressive children are targeted by more negative practices from their parents. In the study by Falcão \& Bolsoni-Silva (2015), after intervention to reduce behaviour problems e realizado pós-teste, mothers increased their emission of childrearing social skills in the interaction with their children; similarly, in the study by Kim et al. (2011), children had their aggressive behaviours decreased and their mothers had their negative practices reduced 
after a teaching procedure of social skills.

Regarding still the pre-school children, boys and children with behaviour problems, further to obtaining associations of positive and negative behaviours with each other, also demonstrated association of positive interaction and social skills with behaviour problems. In relation to boys, behavior problems seemed not to decrease the HSE-P. This result suggests a smaller set of competences (Alvarenga \& Piccinini, 2009) and social skills for these groups. This increases the susceptibility to behaviour problems, especially, externalizing ones (Bolsoni-Silva et al., 2010; Pizato et al., 2014).

Additionally, it is likely that mothers, even though they use positive practices, can not classify which practices would be more reinforced in the interaction in relation to some of their children's behaviours. Thus, these mothers end up emitting an intermittent behaviour pattern in their relationship with their children. This means that sometimes these mothers are skilled, sometimes they are not, considering the same behaviours of their children (Oliveira \& Alvarenga, 2015). Therefore, these mothers do not present behaviour consistency in the relationship with their children. It is also important to point out that social skills were not contrary to behaviour problems. Therefore, in similar contexts, these children may present behaviours with problems as well as skilled ones. Thus, the lack of self-regulation and self-control may constitute a relevant variable (Reyna \& Brussino, 2015).

Hence, concerning the sample of pre-school children, a critical factor in the mutual influence of mothers' behaviours and children was comprised by the variables gende and diagostic for behaviour problems, according to what literature has already indicated (Kim et al., 2011; Sierra \& Veja, 2014). Regarding girls and children without behaviour problems, data suggests that they are able to remain skilled in different contexts, including negative ones (for example, when in Negative Interactions with their mothers). It is also possible to suppose that mothers of boys and children with behaviour problems are not very consistent in their practices, which may contribute, even in mothers' positive situations (for example, in Positive Practices and Interactions), to their children's presentation of behavior problem.

About the sample of school-aged children, for girls and children without behaviour problems there was an association of positive and negative behaviours with each other. However, intriguing data were obtained: positive interaction seemed not to decrease the chances of negative practices and interactions be used. Similarly, the usage of negative practices does not cause a decrease in the chances of the use of positive practices and child's social skills. This possibly means that these mothers use negative and positive practices in similar contexts and children could be able to remain skilled in both situations; the opposite also occurs, even when children are skilled, mothers apply negative practices.

It is possible to assume, from this data, that the evaluated children have a previous history of reinforcement of social skills in different contexts (Vieira, 
Mendes, \& Guimarães, 2010). Another possible explanation is related to these children may have developed a vast set of social competences which taught them about the situations the social skills can be reinforced (Alvarenga \& Piccinini, 2009). For this reason, they might be able to classify that in the face of negative practices from their mothers (such as shouting), demonstrating affection increases the chances of their mothers' behavioural change, for example. Another factor to be considered is that school-aged children demand new behaviours from their parents, what could, at least partially, help the explanation regarding the difficulty at performing parental consistency (Alvarenga et al., 2016).

Studies by McHale et al. (2000) and Sampaio \& Vieira (2010) found results that helped to comprehend the fact that girls at school age present a more complex set of social skills when compared to other groups. According to McHale et al. (2000), mothers used to spend more time with their daughters, as well as fathers used to spend more time with their sons. Due to this reason, the influence of maternal childrearing practices and behavioural models seems to be more intense in girls' behaviours. Additionally, Sampaio \& Vieira (2010) found that girls used to be more frequently exposed to moral behavioural models when compared to boys. Girls were taught about expected behaviours in different environments. However, they were punished more frequently when they did not correspond in accordance to their parents' expectations. On the other hand, boys' problematic behaviours were more acceptable (Sampaio \& Vieira, 2010).

Additionally, the research by Bartholomeu et al. (2016) found that social skills as civility, apologizing, helping others, altruism, gratefulness, assertiveness were associated with positive and negative parental styles. This is the reason why studies should investigate associations between specific maternal and child's behaviours, aiming at better comprehending these kinds of data and findings.

Regarding school-aged boys, the results were compatible with what was expected: as long as mothers used positive practices, children emitted social skills. Similarly, when mothers applied negative practices, the probability of children's behaviour problems emission increased and, in situations of mothers' negative practices, children responded with problematic behaviours (Bolsoni-Silva et al., 2016; Kim et al., 2011). This means that, in this case, mothers seemed to emit a consistent behavioural pattern in the interaction with the children.

Considering the children at school age with behaviour problems, despite of the boys' similar data, one significant association distinguished them: HSE-Conjugal and Negative Interaction. Such association suggests that there could be an agreement between spouses regarding the usage of negative practices in the interaction with children who exhibit behaviour problems.

Therefore, concerning the sample of school-aged children, mothers demonstrated greater behavioural consistency with boys, and a little less in regard to children with behaviour problems. For girls, these mothers demonstrated low consistency, even though children of these groups had indicated more social skills. This difference may have occurred due to a substancial permittivity from parents and educators about disobedience, anger and aggressive behaviours 
emmited by boys compared to girls. For girls, these behaviours are less accepted (Cosentino-Rocha \& Linhares, 2013). These practices increase the chances for boys to aggressively behave in stressful situations in which such aggressivity is accepted. This fact does not favor the learning of social skills; also for this reason, when boys emit skilled behaviours, they may be less valued and reinforced by adults (Cosentino-Rocha \& Linhares, 2013).

In addition, studies (Leman \& Bjomberg, 2010) affirmed the existence of a culturally accepted difference related to the valued behaviours for men and women: for girls, it is taught behaviours of submission, especially when they are coerced, which increases their chances to passively behave in negative situations (Leman \& Bjomberg, 2010) and, thus, skillful behaviours, as self-control and social competence, are more frequently taught and valued when emitted by them (Cosentino-Rocha \& Linhares, 2013).

From a practical point of view, the found results might assist more effectively the elaboration of intervention for children with behaviour problem and their mothers. This is because it makes the identification of behaviour associations more feasible, with higher accuracy, in relation to children with different characteristics.

\section{Conclusions}

In the present study, it was possible to verify similarities in behavioural correlations between girls and children without behaviour problems, moreover, boys and children with behaviour problems, considering children at pre-school and school age. However, the group of girls at school age was the one which presented the most significant data regarding the well developed set of social skills.

By findings in this research, it is reasonable to hypothesise that mothers seem to be more consistent in the upbringing of pre-school children than school-aged children, especially for the girls. This happens possibly because these children are the ones who demonstrate less behaviour problems. It is important to point out that children with behaviour problems also present skilled behaviours, along with the fact that mothers of children with and without behaviour problems use both positive and negative practices in order to raise their children, which suggests behavioural diversity and double directionality in mother-child interactions.

These data emphasise the importance of meticulous investigation of mothers and children's behaviours, in order to find specific behavioural features of this relationship and comprehend which positive and negative practices are mostly utilized with boys and girls, with and without behaviour problems. Finally, it is relevant to consider the limitations of the research, which relied on a relatively small database. Additionally, the applied instruments were based on participants' verbal reports, without correspondence of direct observation, which limitate the generalization of the results and emphasise the need for the conduction of future studies. Another limitation is the fact that the sample was not balanced 
related to gender and school grade. This fact could have biased for the findings; this condition should be controlled in future investigations.

\section{References}

Achenbach, T. M., \& Rescorla, L. A. (2001). Manual for the Achenbach System of Empirically Based Assessment School-Age Forms Profiles. Burlington, VT: Aseba.

Alvarenga, P. A., Weber, L. N. D., \& Bolsoni-Silva, A. T. (2016). Cuidados parentais e desenvolvimento socioemocional na infância e na adolescência: uma perspectiva analítico-comportamental. Revista Brasileira de Terapia Comportamental e Cognitiva, $18,4-21$.

Alvarenga, P., \& Piccinini, C. A. (2009). Práticas Educativas Maternas e Indicadores do Desenvolvimento Social no Terceiro Ano de Vida. Psicologia: Reflexão e Crítica, 22, 191-199. https://doi.org/10.1590/S0102-79722009000200004

Bartholomeu, D., Montiel, J. M., Fiamenghi Jr., G. A., \& Machado, A. A. (2016). Predictive Power of Parenting Styles on Children's Social Skills: A Brazilian Sample. SAGE Open, 1-7. https://doi.org/10.1177/2158244016638393

Berry, D., \& O'Connor, E. (2010). Behavioural Risk, Teacher-Child Relationships, and Social Skill Development across Middle Childhood: A Child-by-Environment Analysis of Change. Journal of Applied Developmental Psychology, 31, 1-14. https://doi.org/10.1016/j.appdev.2009.05.001

Bolsoni-Silva, A. T., \& Loureiro, S. R. (2016). Simultaneous Assessement of Social Skills and Behaviour Problems: Education and Gender. Estudos de Psicologia (Campinas), 33, 453-464. https://doi.org/10.1590/1982-02752016000300009

Bolsoni-Silva, A. T., Levatti, G. E. , Guidugli, P. M., \& Marim, V. C. M. (2015). Problemas de comportamento, em ambiente familiar em escolares e pré-escolares diferenciados pelo gendero. Interamerican Journal of Psychology, 49, 3541-3364.

Bolsoni-Silva, A. T., Loureiro, S. R., \& Marturano, E. M. (2016a). Comportamentos internalizantes: associações com habilidades sociais, práticas educativas, recursos do ambiente familiar e depressão materna. Psico, 47, 111-120.

https://doi.org/10.15448/1980-8623.2016.2.20806

Bolsoni-Silva, A. T., Loureiro, S. R., \& Marturano, E. M. (2016b). Roteiro De Entrevista De Habilidades Sociais Educativas Parentais (Re-Hse-P). São Paulo: HogrefeCetepp, (Teste Psicológico).

Bolsoni-Silva, A. T., Marturano, E. M., \& Loureiro, S. R. (2011). Estudos de Confiabilidade e Validade do Questionário de Respostas Socialmente Habilidosas Versão para Pais-QRSH-PAIS-Pais. Psicologia: Reflexão e Crítica, 24, 1-9.

Bolsoni-Silva, A. T., Marturano, E., \& Rubinger, L. B. (2010) Indicativos de problemas de comportamento e de habilidades sociais em crianças: um estudo longitudinal. Psicologia: Reflexão e Crítica, 23, 187-196. https://doi.org/10.1590/S0102-79722010000300011

Bolsoni-Silva, A. T., Silveira, A. D. M. D., Cunha, É. V. D., Silva, L. L. D., \& Orti, N. P. (2016). Problemas de comportamento e funcionamento adaptativo no teacher's report form (TRF): comparações por gênero e escolaridade. Gerais: Revista Interinstitucional de Psicologia, 9, 141-155.

Bornstein, M. H., Hahn, C. S., \& Haynes, O. M. (2010). Social Competence, Externalizing, and Internalizing Behavioural Adjustment from Early Childhood through Early Adolescence: Developmental Cascades. Development and Psychopathology, 22, 717-735. https://doi.org/10.1017/S0954579410000416 
Bueno, A. C. W., et al. (2011). Comparação entre comportamentos apresentados por mães de pré-escolares clínicos e não clínicos em uma situação lúdica. Revista Brasileira de Terapia Comportamental e Cognitiva, 13, 4-20.

Cosentino-Rocha, L., \& Linhares, M. B. M. (2013). Temperamento de crianças e diferença de Gênero. Paidéia, 23, 63-72. https://doi.org/10.1590/1982-43272354201308

Del Prette, Z. A. (2013). Social Skills Inventory (SSI-Del-Prette): Characteristics and Studies in Brazil. In F. de Lima Osório (Ed.), Social Anxiety Disorders: From Theory to Practice (pp. 49-62). Hauppauge, NY: Nova Science Publishers.

Del Prette, Z. A. P., \& Del Prette, A. (2002). Avaliação de habilidades sociais de crianças com um inventário multimídia: Indicadores sociométricos associados a freqüência versus dificuldade. Psicologia em Estudo, 7, 61-73. https://doi.org/10.1590/S1413-73722002000100009

Emerich, D. R., Rocha, M. M., Silvares, E. F. M., \& Gonçalves, J. P. (2012). Diferenças quanto ao Gênero entre Escolares brasileiros avaliados pelo Inventário de Comportamentos para Crianças e Adolescentes (CBCL/6-18). Psico, 43, 380-387.

Falcão, A. P., \& Bolsoni-Silva, A. T. (2015). Intervention in Social Skills: The Behaviour of Children from the Perspective of Parents and Teachers. British Journal of Education, Society \& Behavioural Science, 11, 1-18. https://doi.org/10.9734/BJESBS/2015/20033

Gomide, P. I. C. (2006). Manual do inventário de estilos parentais: Modelo teórico, manual de aplicação, apuração e interpretação. Petrópolis, RJ: Vozes.

Kim, M., Doh, H., Hong, J. H., \& Choi, M. (2011). Social Skills Training and Parent Education Programs for Aggressive Preschoolers and Their Parents in South Korea. Children and Youth Service Review, 33, 838-845.

https://doi.org/10.1016/j.childyouth.2010.12.001

Konold, T. R. et al. (2010). Relationships among Informant Based Measures of Social Skills and Student Achievement: A Longitudinal Examination of Differential Effects by Gender. Applied Developmental Science, 14, 8-34. https://doi.org/10.1080/10888690903510307

Landale, N. S., Lanza, S. T., Hillemeier, M., \& Oropesa, R. S. (2013). Health and Development among Mexican, Black and White Preschool Children: An Integrative Approach Using Latent Class Analysis. Demographic Research, 28, 1302-1338. https://doi.org/10.4054/DemRes.2013.28.44

Leman, P. J., \& Björnberg, M. (2010) Conversation, Development, and Gender: A Study of Changes in Children's Concepts of Punishment. Child Development, 81, 958-971. https://doi.org/10.1111/j.1467-8624.2010.01445.x

Leme, V. B. R., \& Marturano, E. M. (2014). Preditores de comportamentos e competência acadêmica de crianças de famílias nucleares, monoparentais e recasadas. Psicologia: Reflexão e Crítica, 27, 153-162.

Macedo, L. S. R., \& Sperb, T. M. (2013). Regulação de emoções na pré-adolescência e influência da conversação familiar. Psicologia Teoria e Pesquisa, 29, 133-140.

McHale, S. M. et al. (2000). When Does Parents' Differential Treatment Have Negative Implications for Siblings? Social Development, 9, 149-172.

Meyer, S. B. et al. (2010). Análise do Comportamento e Terapia Analítico-Comportamental. In: E. Z. Tourinho, \& S. V. Luna (Eds.), Análise do Comportamento: Investigações históricas, conceituais e aplicadas (pp. 153-174). São Paulo: Roca.

Newcombe, N. (1999). Desenvolvimento infantil: Abordagem de Mussen. Porto Alegre: Artmed. 
Oliveira, J. M. D., \& Alvarenga, P. (2015). Efeitos de uma intervenção com foco nas práticas de socialização parentais sobre os problemas internalizantes na infância. Revista Brasileira de Terapia Comportamental e Cognitiva, 17, 16-32.

Pizato, E. C. G., Marturano, E. M., \& Fontaine, A. M. G. V. (2014). Trajetórias de Habilidades Sociais e Problemas de Comportamento no Ensino Fundamental: Influência da Educação Infantil. Psicologia: Reflexão e Crítica, 27, 189-197.

Reyna, C., \& Brussino, S. (2015). Diferencias de edad y género en comportamiento social, temperamento y regulación emocional en niños argentinos. Acta Colombiana de Psicología, 18, 51-64. https://doi.org/10.14718/ACP.2015.18.2.5

Reynolds, M. R., Sander, J. B., \& Irvin, M. J. (2010). Latent Curve Modeling of Internalizing Behaviours and Interpersonal Skills through Elementary School. School Psychology Quarterly, 25, 189-201. https://doi.org/10.1037/a0021543

Sampaio, I. T. A., \& Vieira, M. L. A. (2010). Influência do Gênero e Ordem de Nascimento sobre as Práticas Educativas Parentais. Psicologia: Reflexão e Crítica, 23, 198-207. https://doi.org/10.1590/S0102-79722010000200002

Sierra, A. V., \& Vega, M. G. P. (2014). El papel de los esquemas cognitivos y estilos de parentales en la relación entre prácticas de crianza y problemas de comportamiento infantil. Avances en Psicología Latinoamericana, 32, 389-402.

Teixeira, M. C. T. V., Marino, R. L. F., \& Carreiro, L. R. R. (2015). Associations between Inadequate Parenting Practices and Behavioural Problems in Children and Adolescents with Attention Deficit Hyperactivity Disorder. The Scientific World Journal, 2015, Article ID: 683062.

Vieira, T. M., Mendes, F. D. C., \& Guimarães, L. C. (2010). Aprendizagem Social e Comportamentos Agressivo e Lúdico de Meninos Pré-escolares. Psicologia: Reflexão e Crítica, 23, 544-553. https://doi.org/10.1590/S0102-79722010000300015 